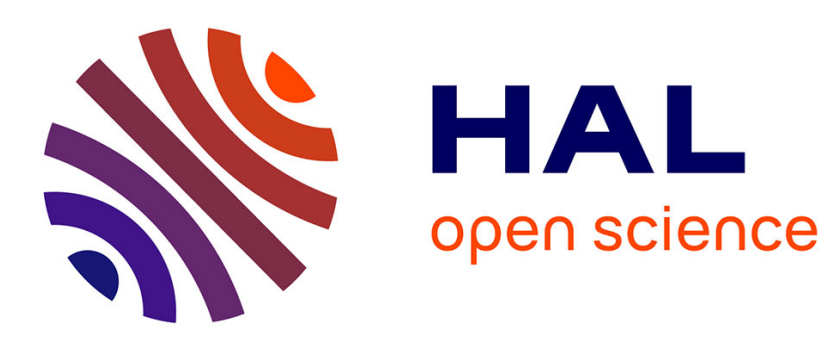

\title{
The impact of the European Union Emission Trading Scheme on Multiple Measures of Economic Performance
}

\author{
Giovanni Marin, Marianna Marino, Claudia Pellegrin
}

\section{To cite this version:}

Giovanni Marin, Marianna Marino, Claudia Pellegrin. The impact of the European Union Emission Trading Scheme on Multiple Measures of Economic Performance. Environmental and Resource Economics, 2018, pp.551-582. 10.1007/s10640-017-0173-0 . hal-01768870

\section{HAL Id: hal-01768870 \\ https://hal.science/hal-01768870}

Submitted on 14 Jun 2018

HAL is a multi-disciplinary open access archive for the deposit and dissemination of scientific research documents, whether they are published or not. The documents may come from teaching and research institutions in France or abroad, or from public or private research centers.
L'archive ouverte pluridisciplinaire HAL, est destinée au dépôt et à la diffusion de documents scientifiques de niveau recherche, publiés ou non, émanant des établissements d'enseignement et de recherche français ou étrangers, des laboratoires publics ou privés. 


\title{
The impact of the European Emission Trading Scheme on multiple measures of economic performance
}

\author{
Giovanni Marin ${ }^{*}$
}

\author{
Marianna Marino ${ }^{\dagger}$
}

\author{
Claudia Pellegrin
}

\begin{abstract}
The European Emission Trading Scheme (EU ETS) has introduced a price for carbon, thus generating an additional cost for companies that are regulated by the scheme. The objective of this paper is to provide empirical evidence on the effect of the EU ETS on firm-level economic performance. There is a growing body of empirical literature that investigates the effects of the EU ETS on firm economic performance, with mixed results. Differently from the previous literature, we test the effect of the EU ETS on a larger set of indicators of economic performance: employment, average wages, turnover, value added, markup, investment, labour productivity, total factor productivity and ROI. Our results, based on a large panel of European firms, provide a broad picture of the economic impact of the EU ETS in its first and second phases of implementation. Contrarily to the expectations, the EU ETS did not affect economic performance negatively. Results suggest that firms have reacted to the EU ETS by passing-through costs to their customers on the one hand and improving labour productivity on the other hand.
\end{abstract}

Keywords: European Emission Trading Scheme, economic performance

JEL: Q52, Q58

\footnotetext{
Claudia Pellegrin acknowledges financial support from the Swiss National Science Foundation, grant number 147612. We thank Dominique Foray, Gaétan de Rassenfosse, Jo Seldeslacht, Antoine Dechezleprêtre, Pierpaolo Parrotta, Martin Wörter and Simone Borghesi, as well as participants to the IAERE Conference 2015, Competition and Innovation Summer School 2015, ZEW Summer Workshop for Young Economists 2015, EAERE Conference 2015 and 'Economics of innovation, diffusion, growth and the environment' Conference for helpful comments to an earlier version of the paper. The usual disclaimer applies.

*University of Urbino 'Carlo Bo', Italy; SEEDS Ferrara, Italy. E-mail: giovanni.marin@uniurb.it.

$\dagger$ Department of Strategy and Entrepreneurship, ICN Business School, Nancy/Metz; France and Bureau d'Économie Théorique et Appliquée (BETA), Université de Lorraine, France. E-mail: marianna.marino@icn-groupe.fr.

\$Corresponding author. CEMI-CDM-EPFL, Odyssea 4.16 Station 5, 1015 Lausanne, Switzerland. Email: claudia.pellegrin@epfl.ch.
} 


\section{Introduction}

An Emission Trading Scheme (ETS), similarly to other alternative climate change policy instruments, is expected to lead to new costs for companies because it requires firms to either buy permits to pollute or, alternatively, to bear the cost of abating emissions ${ }^{*}$. Therefore, according to the traditional view, an emission trading system is likely to decrease firm economic performance with respect to a no-policy scenario (Coase, 1981; Baumol and Oates, 1988; Palmer et al., 1995).

Indeed, companies subjected to the EU ETS, which is the scheme introduced by the European Union in 2005 to reduce greenhouse gas emissions (Directive 2003/87/EC), have always claimed the risks of losing jobs, reducing competitiveness and decreasing market shares relative to companies outside the EU ETS (with the extreme case of relocation to unregulated countries). Therefore, analyses that attempt to address this issue are of strong policy interest for both industrial emitters and policymakers (Martin et al., 2014). In particular, it is relevant to analyze the economic effects of the European scheme because this scheme constitutes the most important policy tool for climate change mitigation of the European Union and the largest carbon trading market implemented in the world thus far.

Existing ex-post empirical analyses on the impact of the EU ETS on firm performance have reached mixed conclusions. Some studies have found positive effects of the EU ETS on economic performance of companies, whereas other papers have found negative effects or no impact at all (Martin et al., 2016; Convery, 2009).

Our paper investigates the effect of the EU ETS on firm-level economic and financial indicators. As opposed to other recent studies, we evaluate a larger variety of measures of performance. Our paper depicts a broad picture of the phenomenon under analysis

\footnotetext{
* An ETS works in the following way: the regulator, at the beginning of the compliance period, allocates a number of emission allowances (or permits) to the regulated installations, thus setting a maximum cap for emissions. The installations then can trade the allowances according to their pollution needs: installations that need to pollute more will buy permits, whereas installations that need to pollute less will sell permits. At the end of each compliance period, participants to the scheme are required to surrender as much permits as their verified emissions. See the Partnership for Market Readiness and International Carbon Action Partnership (2016) for a recent review.
} 
and provides new insights into the mixed results found in the literature to date. Our analysis is based on a large panel of European firms and our results show, for the first and second phase of the EU ETS (2005-2007 and 2008-2012), how economic/financial indicators of the EU ETS firms have evolved relatively to similar firms that were not involved in the EU ETS.

The paper is organized as follows. Section 2 reviews the recent evidence on the evaluation of the impact of the EU ETS on firm performance. Section 3 describes the data used for our empirical analysis. Section 4 discusses the empirical strategy we adopt. Results are discussed in section 5. Finally, section 6 concludes.

\section{Literature review}

Martin et al. (2016) reviewed the empirical evidence on the impact of the EU ETS on economic performance and competitiveness and pointed out that EU ETS ex-post evaluations are "still very much a work in progress" (Martin et al., 2016, pag. 16). Most empirical studies on the effect of the EU ETS on firm economic performance are very recent and just a few have been published in academic journals. These studies differ substantially in terms of empirical strategy, sectoral and geographical scope and the selection of indicators that they evaluate.

Some studies focus solely on one specific European country. Wagner et al. (2014) analyzed the effect of the EU ETS on employment for a panel of French manufacturing installations. By means of a combined propensity score matching and difference-indifferences approach, they found a strong negative effect on employment in the second phase, precisely a significant reduction of employment of about 7 percent. When moving to the firm level analysis, however, they found no significant effect on employment. Petrick and Wagner (2014), using a similar methodology, found no significant effect of the EU ETS on employment for a sample of German manufacturing firms. They also analyzed the impact of EU ETS on gross output and exports and found no effect on gross output in the first phase but a significant and positive effect in the second phase. Moreover, a positive and significant effect on export was found in both phases. Anger and Oberndorfer (2008) conducted an analysis on revenues and employment on German firms related solely to the first phase of the EU ETS by means 
of an instrumental variable regression. They found no significant effects. Jaraite and Di Maria (2015) focused on Lithuania and analyzed the effect of the EU ETS on investments and profitability. They also used a combined propensity score matching and difference-in-differences approach. They found a slight increase of investments driven by the EU-ETS.

Other studies cover a larger selection of European countries. Abrell et al. (2011) investigated the effect of EU ETS on profit margins, value added and employment on a dataset of European companies. For their analysis, they combined data from the EU ETS Transaction Log with the Amadeus database (Bureau van Dijk). They found no significant impact of the EU ETS on profit margins and value added and a small, but significant, negative effect on employment. Chan et al. (2013) analyzed the impact of the EU ETS on material costs, employment and revenues in the power, cement, iron and steel sectors. Their results show positive effects on material costs and revenues only for the power sector.

Early studies solely investigated the first phase of the EU ETS. Commins et al. (2011) studied the impact of EU ETS on total factor productivity (TFP), returns to capital, employment and tangible investments on a sample of European firms. They found a negative effect for TFP and returns to capital but no significant effect for employment and tangible investments.

Martin et al. (2016) concluded that "one priority for future research on the EU ETS is the further development of firm-level micro-data, in terms of both outcome variables and geographical coverage" (Martin et al., 2016, pag. 16).

Our contribution to this emerging literature is manifold. Compared to existing studies, (i) we evaluate a larger selection of outcome variables, (ii) on a larger selection of EU countries, and (iii) we evaluate whether the effect of the EU ETS differs according to the emission intensity of firms and the role of entry/exit of firms into the treatment group.

\section{Data}

EU ETS allowances are allocated at the installation level. An installation is subjected to the EU ETS if it satisfies both the two following conditions: (i) it should belong to one 
of the sectors listed in the Directive 2003/87/CE "establishing a scheme for greenhouse gas emission allowance trading within the Community" ${ }^{\dagger ;}$ and (ii) it should have an installed capacity above a certain sector-specific threshold. The European Union Transaction Log (EUTL) is the register containing information regarding obligated installations, which are around 11000 and represent around the 40 percent of total European GHG emissions.

Our analysis focuses on firms that operate in the manufacturing sector. Differently from the power sector (and other non-tradable sectors), manufacturing firms are exposed to international competition, which may limit the possibility to pass-through the additional cost imposed by the EU ETS to its customers. This means that the burden of dealing with the EU ETS may be particularly relevant for manufacturing firms, thus raising the concern of loss of international competitiveness of EU firms and, consequently, job losses in the EU manufacturing sector. Relocation of emission-intensive manufacturing production abroad in response to the EU ETS may even impair the environmental effectiveness of the EU ETS as in that case emissions would just be moved abroad (carbon leakage, see Martin et al, 2014). Finally, it should be noted that installations in the manufacturing sector accounted for an important share of GHG emissions covered by the EU ETS: 32.8 percent of GHG emissions covered by the EU ETS over the period 2005-2012 are due to the manufacturing sector.

Despite the fact that the participation to the EU ETS is assigned at the installation level, our analysis is performed at the firm level. This is because data on economic performance (i.e. balance sheet and income statement accounts) is only reported for firms and not for installations. Therefore, it is essential to establish the link between the EU ETS accounts at the installation level and the corresponding parent companies. We

\footnotetext{
† Annex I of the Directive 2003/87/CE reports sectors covered by the scheme: energy-intensive industry sectors including oil refineries, steel works and production of iron, aluminium, metals, cement, lime, glass, ceramics, pulp, paper, cardboard, acids and bulk organic chemicals production of nitric, adipic, glyoxilic and glyoxylic acids, aluminium production; power and heat generation. Commercial aviation has been introduced starting from the second phase.

\$ Sector-specific thresholds are reported in Annex I of the Directive 2003/87/EC (and subsequent amendments). We just report two examples of sector-specific thresholds, which is combustion installations with a rated thermal input exceeding 20 MW (except hazardous or municipal waste installations) and installations for the production of pig iron or steel (primary or secondary fusion), including continuous casting, with a capacity exceeding 2.5 tonnes per hour.
} 
link each installation in the EUTL to its corresponding parent company (direct owner) in Amadeus by means of its national unique identifier ${ }^{\S}$.

To retrieve the firm-level economic information to build our indicators of economic performance, we use the Amadeus database (Bureau van Dijk), which is a database that contains financial and business information for medium and large European companies. Precisely, Amadeus includes standardized annual accounts (consolidated and unconsolidated), financial ratios, sectoral activities and ownership data. As the EU ETS began in 2005 and we want to observe a sufficiently large pre-treatment period, we extend the current release of Amadeus (extracted in July 2014, coverage 2004-2012) with a previous release of Amadeus (firms observed from 2002 to 2010) ${ }^{* *}$.

The firms that are registered in the EUTL as 'Account Holder' are the direct owners of the installations. These firms, in turns, may be subsidiaries of other firms, up to the ultimate owner. An approach involving the ultimate owner firm instead of the direct owner firm would imply a weaker link between the installation and the corresponding firm, as the ultimate owner is often a holding company or a large multinational group that operates in several sectors and countries. As the EU ETS may in principle impact both the direct owner and, to a lesser extent, the intermediate and ultimate owners, we exclude ultimate or intermediate owners of EU ETS firms that do not own directly any EU ETS installation from our analysis to avoid their presence in the control group ${ }^{\dagger \dagger}$. To this extent, we control for ownership links and changes in ownership (mergers and acquisitions) using information from the Amadeus and Zephyr databases (Bureau van Dijk).

\footnotetext{
$\S$ When the identifier of the parent firm in the EU Transaction Log is missing, we match companies to EU ETS installations by means of firms' name and address.

** Due to changing firm identifiers, we had to exclude those firms for which information on financial accounts was not consistent between the two releases in the overlapping years. This check leads us to exclude about 4.8 percent of firms.

${ }^{\dagger 1}$ Imagine that firm A is the direct owner of an installation covered by the EU ETS. Firm A is part of a broader group of firms. More specifically, firm A is owned by firm B (intermediate owner) that, in turn, is owned by firm C (head of the group, ultimate owner). We expect the ETS to have its most direct impact on firm A. However, firm B and C may be indirectly influenced and may respond to the ETS as they control firm A. In our analysis, firm A is the treated firm, while firm B and C are removed from the analysis as they are not suitable counterfactual, being at least indirectly treated.
} 
For the 19 countries that we analyse (EU28, with the exception of Bulgaria, Croatia, Cyprus, Greece, Ireland, Lithuania, Luxembourg, Malta and Romania ${ }^{\ddagger}$ ), we match 5030 ETS installations to 3445 manufacturing firms, as it is shown in Table 1.

[Table 1 about here]

Overall, these represent 74.1 percent of the ETS manufacturing installations in these countries and account for 88.1 percent of verified emissions from ETS manufacturing installations over the period 2005-2012.

We evaluate the impact of the EU ETS on the following measures of economic and financial performance: number of employees, average wages (average labour compensation per employee), turnover, value added, markup, investment intensity (gross fixed capital formation over total assets), labour productivity (value added over total number of employees), total factor productivity (TFP) and return on investment (ROI). Monetary variables, expressed in euro, have been deflated to 2005 prices using country, sector and variable specific deflators from Eurostat. We estimate TFP using the procedure developed by Ackerberg et al. (2006), whereas estimates of firm-specific markup (expressed as the ratio between price and marginal cost) are based on the procedure developed by De Loecker and Warzynski (2012). According to De Loecker and Warzynski (2012), the markup can be estimated as the ratio between labour share of total costs and the elasticity of value added to labour input, which is estimated with a translog production function. As a lag in the inputs of the production function is needed to estimate its parameters, TFP and markup can only be estimated from year 2003 onwards for those observations for which at least two consecutive years were available for all variables. Further details on the estimation of TFP and markup are reported in Appendix A.

Regarding the period of our analysis, we focus over the first and the second phase of the EU ETS: 2005-2007 and 2008-2012 respectively. The first phase of the EU ETS (2005-

\$ Three EU countries entered the EU ETS after 2005: Bulgaria (2007), Romania (2007) and Croatia (2013). For the remaining excluded countries (Greece, Ireland, Luxembourg, Cyprus, Lithuania, Malta), no information was available for some of our outcome variables for all firms. Despite not being part of the EU28, three countries (Norway, Iceland and Lichtenstein) participate to the EU ETS but only since 2008 and therefore are excluded from our analysis. 
2007) was a pilot phase: no banking or borrowing of permits with the subsequent phases was allowed and allowances were allocated for free (grandfathering) ${ }^{\S \S}$. The second phase began in 2008. The main differences with respect to the first phase were: higher penalty for non-compliance (from $40 €$ per ton of $\mathrm{CO}_{2}$ in the first phase to $100 €$ per ton); the inclusion of $\mathrm{N}_{2} \mathrm{O}$ emissions; possibility of banking of permits across phases. Grandfathering remained the default allocation method. Comparing the actual stringency of the two phases is not straightforward. Prices were quite high (around 30 euros per ton of CO2) in 2005 but collapsed to almost zero by mid-2006. Thank to banking, prices were relatively more stable in the second phase (2008-2012), even though prices fell sharply from about 30 euros per ton in 2008 to less than 10 euros per ton in 2012, also because of the Great Recession.

As pre-treatment time span for our matching exercise, we take the period 2003-2004. We keep firms for which at least one outcome variable is observed at least once in each of the three-time windows we consider for our analysis: pre-treatment period, first phase and second phase of the EU ETS. Therefore, the estimation sample changes for each outcome variable.

Not all EU ETS installations have been subjected to the scheme since the beginning or until the end of our period of treatment (2005-2012). Some installation was built or became eligible for the inclusion in the EU ETS over the period, while some other was shut down or modified in a way that was not anymore eligible for inclusion in the EU ETS (e.g. by reducing its production capacity below the threshold). We exclude these installations from our main sample, in order to have only firms which are present in each time window of our analysis (pre-treatment period, first phase, second phase). This leads to an increase of internal validity of our analysis but may limit the possibility to generalize them to the population of ETS firms (i.e. external validity). In this light, we

\footnotetext{
$\S \S$ "Grandfathering" is one of the possible methods of allocation of the pollution permits from the central authority to the emitters, at the beginning of the compliance period. Grandfathering consists in the free allocation of pollution permits, as opposed to auctioning of permits. Auctioning increases the stringency of the policy as it entails a net transfer of monetary resources from firms to the government. The rationale for grandfathering has been, indeed, to decrease the stringency of the policy in order to alleviate possible risks of completion losses.
} 
offer some descriptive evidence about the likely impact of entry-exit from the scheme on performance.

Due to missing information for certain variables and panel attrition, our final operative sample of treated firms is composed of 1636 EU ETS firms that own a total of $2667 \mathrm{EU}$ ETS installations. The distribution of linked installations and firms by country and sector in our operative sample is reported respectively in Table 2 and Table $3^{* * *}$.

[Table 2 and Table 3 about here]

Our operating sample represents 39.3 percent of the EU ETS manufacturing installations in our group of 19 countries, accounting for as much as 54.4 percent of emissions over the period 2005-2012.

\section{Estimation approach}

\subsection{Identification strategy}

The challenge related to the empirical ex-post policy evaluation of the impact of the EU ETS is to establish a causal link between the policy itself and changes in the outcome variable. The treatment group includes firms that own at least one installation that participates in the EU ETS, whereas the control group is composed of similar non-EU ETS firms. As discussed by Calel and Dechezleprêtre (2016) and Jaraite and Di Maria (2015), matching on observable characteristics is problematic when dealing with installation-level data. This is due to the rules that govern the assignment to treatment within the EU ETS: the scheme covers all installations operating in participating countries that have installed capacity above certain sector-specific thresholds. This means that it is not possible to find a good match for an EU ETS installation given that

\footnotetext{
*** It is useful to summarize how we get to our final operative sample. We initially linked 5093 manufacturing EU ETS installations to 3503 firms in our 19 European countries (Table 1). By excluding those firms for which no information on any of our outcome variables is available, we reduce our sample to 2798 EU ETS firms (4307 installations). We further excluded firms for which the primary NACE code does not belong to the manufacturing sector, leading to a sample of 2542 EU ETS firms (3756 installations). Then we selected firms with more than 10 employees (on average) and firms for which at least one of the outcome variables is observed at least once in each of our three relevant time windows (pre-treatment, first phase and second phase). Finally, we selected firms whose installations are always present in all the three time windows, we obtain our operative sample of 1636 firms (2667 installations).
} 
any other installation with the same size (in terms of installed capacity) operating in the same sector should be treated too. However, as suggested by Calel and Dechezleprêtre (2016) and Jaraite and Di Maria (2015), when the unit of observation is the company instead of the installation, the following situation may occur: within the same sector and size class (not in terms of installed capacity, but in terms of, for example, employment, assets or turnover), there may exist at least one company owning one or more installations, which are sufficiently large to be covered by the EU ETS and at least one company with no installations that meet the criteria for participating to the EU ETS. As firm size and sector of operation (together with other features) matter more for overall company performance than does installed capacity of each and every installation, when using the firm as the unit of analysis, it is possible to have a common support between the treated and the control group in terms of observable characteristics.

To analyze the impact of the EU ETS, we apply a difference-in-differences approach with matching on pre-treatment firm's characteristics (semi-parametric difference-indifferences estimator, Abadie, 2005).

As exact matching on multiple dimensions is characterized by the issue of dimensionality (see Caliendo and Kopeinig, 2008, for a review), we decided to match treated firms to untreated ones on the estimated propensity score (Rosenbaum and Rubin, 1983; Rosenbaum and Rubin, 1985). The propensity score is the estimated probability of being treated given a set of observable characteristics of treated and untreated units. The use of a single synthetic variable that combines information about a variety of dimensions eliminates the dimensionality issue and allows exploiting efficiently the information contained in continuous variables. Conditional on the propensity score, the treatment is assumed to be independent and the identification of the average treatment effect on treated is achieved. We estimate the probability of being treated as a function of the following pre-treatment characteristics (measured in 2003): number of employees (in $\log$ ) to account for firm size, growth rate of the number of employees (2003-2004), capital intensity (log of fixed assets per employee), growth rate of labour productivity (value added per employee, in log), age of the company. In addition to this list of variables common for all outcome variables, for each outcome variable we also include in the estimation of the propensity score the pre-treatment level (2003) and the growth (2003-2004) of the outcome variable itself. This is intended to 
force treated and control firms to have similar levels and parallel trends (growth) of the outcome variable before the treatment.

To account for unobserved shocks, such as the Great Recession of 2008-2009, that had a differential influence on different sectors and countries, we force treated firms to be matched with untreated firms belonging to the same country and sector pair (exact matching, see e.g. Calel and Dechezleprêtre, 2016). With exact matching on sectorcountry, we partial out these macroeconomic unobserved shocks in a flexible way. Exact matching on country-sector, however, reduces the pool of potential untreated matches, especially so for small countries and sectors, thus limiting the possibility to find a proper counterfactual for ETS firms operating in small country-sector cells, limiting the possibility to generalize the results to the entire set of ETS firms. In a robustness check we do exact matching on sector only, thus reducing the number of ETS firms for which we were not able to find an appropriate counterfactual. Results remain robust to this change.

After estimating the propensity score and matching treated and control firms, we estimate the impact of the EU-ETS (average treatment effect on the treated, ATT) on our outcome variables, separately for the two phases of the scheme (2005-2007 and 2008-2012) as:

ATTPhase I=EYiPhase I-Yipre-ETSETSi=1-E(YiPhase I-Yipre-ETS/ETSi=0, Matchi=1)

ATTPhase II=EYiPhase II-Yipre-ETSETSi=1-E(YiPhase II-Yipre-ETS/ETSi=0, Matchi=1)

The assumption is that in absence of the treatment, the trend of treated and untreated firms would have been the same.

Ideally, inference about the estimated average treatment effect on the treated should account for the fact that matching is performed on the estimated propensity score and not on the true one. Uncertainty about the estimate of the propensity score should be accounted for while estimating the confidence interval of the treatment effect. To do so, our inference is based on the heteroskedasticity-consistent analytical standard errors proposed by Abadie and Imbens (2006).

\subsection{Validity of identifying assumptions: common trends assumption, SUTVA and endogenous selection into treatment}


The validity of the difference-in-differences method relies on the assumption that the trend of the outcome variable would have been the same, in both the treatment and the control group, in the absence of the policy. This assumption cannot be tested explicitly. Our empirical strategy is aimed at reducing the risk that this assumption is violated, mainly by including the pre-treatment growth of the outcome variable as a covariate in the estimation of the propensity score. In this way, we select as controls only firms that have a similar trend to that of treated firms in the pre-treatment period.

Another assumption that is needed for the estimate of the average treatment effect to be unbiased is that the treatment has no impact on untreated firms (Stable Unit Treatment Value Assumption - SUTVA). Our empirical results may be partly affected by the possible failure of the SUTVA for two reasons. The first one is related to the fact that matched firms are likely to operate in the same market of treated firms. For a given demand function, changes in the market share of treated firms necessarily implies changes (of opposite sign) in the market shares of firms belonging to the control group. This issue may be particularly relevant for highly concentrated markets/sectors. The failure of the SUTVA would possibly lead to effects of opposite sign in terms of turnover, firm size and markup, between the two groups of firms (treated and control group) if we expect to be in a zero-sum game within the same market. That means that both a positive or negative effect are likely to be, if anything, overestimated in absolute terms. The second possible reason for the SUTVA to fail is related to spillover effects through general equilibrium impacts. For example, Sijm et al. (2006) found that the power sector is estimated to pass-through about 60-100 percent of $\mathrm{CO}_{2}$ to cost by increasing electricity prices. This increase in electricity price, induced by the ETS, will influence other manufacturing firms, including non-ETS ones.

A third possible threaten to unbiased identification of the treatment effect refers to the possibility that firms may manipulate the size of their production installations with the aim of maintaining them below the sector-specific threshold, above which the installation must comply with the EU-ETS. On the one hand, ETS firms may have the incentive to reduce the size of their plants just below the threshold. That would entail, however, substantial sunk costs, especially for installations that were recently built. On the other hand (and more importantly), non-ETS firms may have the incentives to increase the capacity of their installations just below the sector specific threshold to 
remain outside the EU ETS. That would result in a lower than expected firm growth for untreated firms, creating a potential bias for scale-related variables.

\subsection{Propensity score and matching}

The propensity score is estimated with probit. To accommodate for different distributions of missing values across firms for each of our measures of performance, we estimate a different propensity score for each outcome variable. Results of the estimations of the propensity score for each outcome variable are reported in Table 4.

[Table 4 about here]

The probability of being treated (i.e. the probability of owning an EU ETS installation) is positively and significantly related to firm size (employment), capital intensity and labour productivity in all specifications of the propensity score. Age and firm size growth, on the contrary, do not correlate with the likelihood of being treated. Firms with higher average wages, turnover, markup, growth rate of value added and growth rate of ROI are more likely to be treated, whereas ROI in levels is negatively correlated with the likelihood of being treated ${ }^{\dagger \dagger \dagger}$.

Based on the estimated propensity scores, we match each EU ETS firm to a maximum of 10 nearest neighbours (in terms of estimated propensity score) non-ETS firms. A large number of selected nearest neighbour improves the efficiency of the estimate (smaller variance) but increases the expected bias (see Caliendo and Koeping, 2008). As a robustness check, we also report results based on one nearest neighbour matching. To reduce the risk of selecting firms that are not sufficiently similar to treated firms, we also impose a caliper of 0.05 : control firms that are not sufficiently similar (i.e. the distance in terms of the estimated probability of being treated with the corresponding treated firm is greater than 5 percent) are not included in the counterfactual, even if they fall in the group of the 10 nearest neighbours. Finally, treated firms that lie out of the support of estimated propensity score for potential controls are excluded from the analysis. Table 5 reports details about the number of treated firms, the number of treated

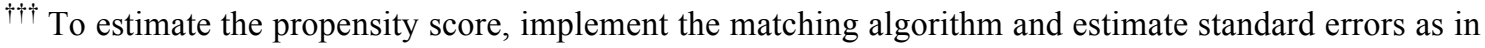
Abadie and Imbens (2006) we employ the user-written STATA command psmatch2.
} 
firms out of the support or unmatched, the number of matched controls and the average number of matched controls per treated firm.

[Table 5 about here]

The smallest coverage is for markup and TFP, because the estimation of these two measures (refer to Appendix A) requires observing their employment, capital stock, value added and turnover (also wage bill for markup) for at least two consecutive years. The number of EU ETS firms that have no suitable match within the caliper ranges from 221 firms for TFP to 297 for employment.

In Table 6 and Table 7 we report information about the quality of the matching and its contribution in reducing the differences between the treated and the control group.

[Table 6 and Table 7 about here]

In Table 6 we report the difference between treated and control firms (bias) for the level and growth rate of each outcome variable. Moreover, we report a synthetic measure of 'average bias' (that accounts for all the variables included in the propensity score) and a synthetic statistic (Chi squared) about the joint statistical significance of the bias. Results for the remaining variables that were included in the estimation of the propensity score are reported in Table 7. After matching on the propensity score, treated and control groups are not statistically different, on average, in the pre-treatment level and growth rate of all our measures of economic performance, whereas the differences in the same dimensions between treated companies and the full sample of potential controls were often large and statistically significant. In all cases, our synthetic measure of relative bias is not statistically significant (Chi squared test) and very small in magnitude (the maximum average bias is 4.9 percent for turnover). The fact that we do not find differences in the growth of our outcome variables in the pre-treatment period between the treated and the control group adds support to the assumption of absence of differences in pre-treatment trends between the two groups that could have impaired our difference-in-differences approach.

When considering the other variables (Table 7), the matching generally results in insignificant differences between treated and control group in all variables with the exception of capital intensity, that is larger (significant at 5 or 10 percent level) for ETS than for matched non-ETS firms. All in all, the matching on propensity score allows 
building a counterfactual group that resembles the treated group in the observed dimensions.

\section{Results}

Before discussing the results of our estimates, we look at descriptive trends in average measures of economic performance for treated and control firms (matched controls solely, weighted by matching weights) over the period that we consider (Figure 1$)^{1+*}$.

[Figure 1 about here]

A few clear patterns appear by evaluating average trends in treated and control firms. The financial crisis has negatively influenced most measures of performance in 2008 and 2009, with the exception of wages. The largest observed differences between the treated and the control group after 2005 appear in the trends of turnover, markup and labour productivity. The major substantial departures in trends between the two groups of firms seem to be 'in favour' of EU ETS firms for these three variables, while evidence is more mixed for other variables.

\subsection{Baseline results}

Table 8 reports the results of our baseline estimates of the average treatment effect on the treated for our set of performance measures.

[Table 8 about here]

Contrarily to the expectations based on the traditional approach about the impact of environmental policy on economic performance, according to which an environmental policy should have a negative impact on firm economic performance, Table 8 shows no systematic negative effects of the EU ETS on the considered dimensions of economic performance. We actually find positive impacts on some of the performance measures under analysis, larger in magnitude in the second phase of the scheme. More specifically, a strong positive effect is found, in both the two phases, for markup and

\footnotetext{
$\$$ Given that the yearly panel is unbalanced, variables were interpolated and extrapolated within the firm to obtain a balanced panel.
} 
investment intensity and, only for the second phase, for turnover and labour productivity. The predicted additional increase in turnover for ETS firms in the second phase of the ETS with respect to the pre-ETS period is $6.4 \log$ points (6.6 percent). Higher turnover, coupled with a not significant effect on value added, suggests that the EU ETS, while driving up sales, has also increased the cost of materials and external costs (that represent the difference between turnover and value added) for ETS firms.

The impact of the EU ETS on markup is positive and significant both in the first and the second phase. In the first phase, treated firms witnessed an increase in markup of about 1.5 percent larger than non-treated firms. This gap widened during the second phase amounting to a point estimate of 3.2 percent. This result suggests that our treated firms, even though they belong to the 'tradable' manufacturing sector, have passed-through the additional costs imposed by the EU ETS to their customers. These results are in line with the findings of the model by Demailly and Quirion (2008) that predict a substantial pass-through of ETS costs for the iron and steel manufacturing sectors.

Combining our estimates for turnover and markup in Phase II we calculate that, assuming a stable physical output, the ETS has induced an increase in marginal costs of production in the order of about 3.8 percent $^{\S \S \S}$.

Looking at the employment impact of the ETS, a particularly sensitive issue for policy makers in a recessionary period as the one we are considering, a small (2.16 log points, 2.18 percent) and weakly significant negative effect is estimated for the phase 20052007 , but this effect disappears in the second phase ${ }^{* * * *}$. Overall, our estimates suggest

\footnotetext{
$\S \S \S$ We thank an anonymous referee for suggesting this approach for quantifying the impact on marginal cost. To compute the expected increase in marginal cost (for given physical output) we take the ratio $(-1)$ of 1 plus the predicted relative increase in turnover for ETS firms and the predicted relative increase in markup for ETS firms. More specifically, we compute the following equation:

$\Delta * * * * * 1+()-1$

**** Results for employment are confirmed when using total compensation paid to employees instead of the number of employees. The 'employment' variable reported in the Amadeus database is sometimes estimated or interpolated rather than collected from administrative data. For this reason, it is useful to evaluate alternative proxies such as total compensation to employees. The EU ETS had no effect on total compensation paid to employees in the two phases, with point coefficients of -0.0157 in the first phase (pvalue 0.24 ) and -0.0061 in the second phase ( $p$-value 0.79$)$. The point estimates are similar to the ones estimated for employment.
} 
that concerns about job losses due to the introduction of the emission trading were overestimated, also due to the unexpectedly low price of emission allowances.

The absence of impacts on wages reflects, on the one hand, the rigidity of wages in EU countries and, on the other hand, negligible impacts of the EU ETS on the structure of the labour force towards jobs with wages above or below the average. Not significant effects are also estimated for TFP and ROI, suggesting a negligible influence of the EU ETS on Hicks-neutral technological change (i.e. TFP) and profitability.

Investment intensity has been influenced positively by the EU ETS in both the first and the second phase, with a predicted increase of, respectively, 1.26 and 1.56 percent of total assets. Moreover, we find a positive and significant impact of the EU ETS (second phase only) on labour productivity (5.04 log points, around 5.17 percent). As neither TFP nor wages (i.e. human capital) were influenced by the ETS, we may infer that the improvements in labour productivity are the result of capital deepening. These additional investments may have been directed toward new more energy-efficient equipment and machinery in substitution of existing capital goods. Unfortunately, however, our data do not allow us to test this hypothesis.

When we compare the treatment effect of the first and the second phase (both estimated with respect to the pre-treatment period), this difference turns out to be statistically significant for turnover, value added, markup and labour productivity.

Our estimates suggest that there are two possible ways to recover the additional costs imposed by the EU ETS. The first way consists in charging higher prices on the final product (through higher markup); the second way is to increase the investment intensity and/or, accelerate the rate of substitution of old capital stock with new (likely more energy efficient) capital.

\subsection{Robustness checks}

A possible bias in our baseline estimates may arise because many treated firms have been excluded from the analysis when no suitable match was found within the caliper and the country-sector cell. As a robustness check, we loosen the match by allowing ETS firms to be matched to non-ETS firms within the same sector but in any other country (exact matching only on sector). 
[Table 9 about here]

Results are reported in Table 9. The estimated treatment effect remains generally robust in sign, magnitude and statistical significance, the only relevant differences being the absence of a significant effect on investment intensity and a predicted increase in TFP of about 1.4 percent in the first phase only.

In a second robustness check, we evaluate a different choice about the matching algorithm. Differently from our baseline results, we now only match one nearest neighbour to each treated firm, while maintaining the same caliper (0.05). As discussed in section 4.1, there is a trade-off between efficiency and bias in matching estimators: reducing the number of matched nearest neighbours increases the similarity between the treated and control groups (limiting the bias) but also increases the variance of the estimator as some information is not used in the estimate. On the contrary, an increase in the number of matched nearest neighbours entails a worse match (larger bias) but increases the precision of the estimate. Results are reported in Table 10.

[Table 10 about here]

Results remain robust in terms of sign, magnitude and statistical significance (or absence thereof). In line with the former robustness check, the impact of the ETS on investments intensity turns to be not statistically significant. The weakly negative effect on employment now disappears, while we now estimate a positive effect on turnover also in the first phase and a positive significant effect on value added appears in the second phase.

As third robustness check, presented in Table 11, we test whether our baseline results are sensitive to the exclusion of the matching on pre-treatment growth rate of the outcome variables. This is particularly relevant as these variables are the ones for which we observe many missing values, thus reducing the sample of firms in our baseline estimates.

[Table 11 about here]

The effect on investment intensity is not significant and there is a positive effect on value added in the second phase. The negative effect on employment in the first phase 
becomes slightly more significant but similar in magnitude, while we estimate a small but significant positive impact of the ETS on average wages during the first phase.

Overall, our set of robustness checks confirms the results of our main specification: the strong positive impact of the ETS on markup (both phases), turnover and labour productivity (second phase only).

\subsection{Impact of emission intensity as proxy for ETS stringency}

To gain a deeper understanding of the role played by the EU ETS in influencing economic performance of firms, we examine whether the impact of the EU ETS varies depending on how exposed is the firm to carbon pricing, proxied by its emission intensity. The hypothesis we test is to what extent firms that rely on emission-intensive processes are likely to suffer more (or gain less) from carbon pricing than firms with less emission-intensive processes. We expect a 'worse' economic performance induced by the EU ETS for more emission-intensive firms as they should pay a larger share of their revenues to purchase emission permits.

It should be noted, however, that emission intensity is not randomly assigned. Systematically more emission-intensive firms may be characterized by unobserved heterogeneity that also influences their performance beyond the role played by the EU ETS. For this reason, results should not be interpreted in a causal way.

For each outcome variable and each time window, we estimate the link between firmspecific average emission intensity (average firm-level verified emissions over 20052012, retrieved from the EU ETS registry, divided by average turnover over the same period) and the growth in the outcome variable. The estimation equation (estimated with OLS) is:

\section{$\Delta Y i$ ETSi $=1=\beta \times C O 2 \_$emissi/turnoveri $+\eta c s+\varepsilon i$}

where $\eta c s$ are country-sector dummies.

\section{[Table 12 about here]}

Result in Table 12 show that the exposure to carbon pricing is not systematically linked to our set of outcomes. We only find a weak $(p<0.1)$ positive link of emission intensity with value added and labour productivity in the first phase and a slightly stronger link of 
emission intensity with TFP in the second phase. A possible reason may be that more emission-intensive firms are the ones that have greater incentives to re-organize their production processes, leading to productivity improvements, as they may gain more from reducing emissions in presence of a price for carbon.

\subsection{Entry into and exit from the EU ETS}

Our baseline results discussed in section 5.1 cannot be generalized to the population of ETS manufacturing firms with more than 10 employees. The first reason is related to the failure to consider the entry of new firms on the market and firm survival. Indeed, we condition on the existence of the firm on the market and in the dataset in the pretreatment period and on the survival of the firm over the entire treatment period. We face methodological challenges in evaluating the impact of the ETS on new firms, as our outcome do not exist in the pre-treatment period. On the other hand, exit from the market may be an outcome variable per se. The main issue in constructing an exit outcome variable is that, given our data (Amadeus), it is very hard to disentangle panel attrition from actual exit. The failure to account for firm exit would go in the direction of providing overly optimistic estimates of the impact of the ETS on performance.

A second reason of concern for the generalization of results is that, within the group of treated firms that remain on the market for the entire period, we just select the ones that are treated for the entire period (2005-2012), while firms that only participated to Phase I (exiting the ETS in Phase II but not leaving the market) or to Phase II (entering the ETS in Phase II but already on the market in pre-ETS and Phase I periods) are not considered in the analysis. Entry in the ETS may occur if: i) a firm acquires an installation already covered by the scheme; ii) an existing firm builds a new installation that satisfies the requirements for entering the ETS; iii) a firm enlarges the production capacity of an existing installation above the thresholds. Similarly, exit from the ETS may occur if: i) a firm sells an installation covered by the scheme to another firm; ii) a firm shuts down an installation covered by the scheme; iii) a firm reduces the production capacity of an existing installation below the thresholds.

To provide descriptive evidence about the difference in performance between our sample of continuing firms and firms that entered or exited the EU ETS (but were on 
the market for the entire period), we estimate the link between the growth in the outcome variables and the status of 'entrant' or 'exiting' (into and from the ETS) firm:

$\Delta Y i$ ETS $i=1=\beta$ Entry_PhaseIIi $+\gamma$ Exit_PhaseIIi $+\eta c s+\varepsilon i$

where Entry_PhaseIIi is equal to one if firm $i$ did not participate to Phase I of the ETS but did participate to Phase II (and is zero otherwise), Exit_PhaseIIi is equal to one if firm $i$ participated to Phase I of the ETS but left the scheme (not the market) during Phase II (and is zero otherwise), $\eta c s$ are country-sector dummies.

[Table 13 about here]

Results are reported in Table 13. Concerning exit (119 firms), performance of exiting firms during the first phase (Panel A) is comparable to that of always-present ETS firms, with the only weakly significant differences being a lower increase of investment intensity for exiting firms and a higher increase in wages. When these firms exit the EU ETS in Phase II (Panel B), employment substantially shrinks (-30.4 log points, -35.5 percent), as well as turnover (-25.7 log points, -29.3 percent). This means that either these firms where hit by a big shock that forced them to reduce their scale of production and subsequently falling below the thresholds for participating to the ETS, or they decided to downsize their production capacity with the specific aim of being exempted from the ETS. Interestingly, these firms also experience a reduction in markup $(-12.3$ percent) with respect to firms that remain in the ETS.

Concerning entry (166 firms), we find less clear differences in performance with respect to always-present firms. Entering firms experience a substantially higher increase in investment intensity growth with respect to ETS firms that were already in the scheme during the first phase (Panel A). This may indicate that these firms expanded their production capacity, thus passing the threshold to participate to the ETS. These firms also experience a higher TFP growth and a higher (but weakly significant) growth in wages with respect to continuing ETS firms. Once entered the scheme (Panel B), these entrant firms experience a substantially faster growth in turnover (11.6 log points, only weakly significant) and value added with respect to always-present ETS firms, suggesting that entry into the scheme was accompanied by an expansion in production. 
Interestingly, these firms experienced faster TFP growth than other ETS firms did during both phases.

On the one hand, results about exit from the ETS suggest that our baseline estimates may be overly optimistic regarding the effect of the ETS on employment, turnover and markup in the second phase because the reduction in employment, turnover and markup in the period 2008-2012 for these firms could be related to their earlier (2005-2007) participation to the ETS. On the other hand, however, findings about entry in the ETS suggest that our baseline estimates may be overly pessimistic for value added and TFP in the second phase $\mathrm{it \dagger}^{\dagger+}$. It should be noted, however, that entry and exit from the ETS only involve a limited number of companies in our sample of ETS firms: 166 for entry (about 9 percent) and 119 for exit (about 7 percent). This means that even if we were able to account for these firms, results would have not differed substantially to the ones discussed earlier in the paper.

\section{Conclusions}

In this paper, we evaluate the impact of the EU ETS on economic performance of firms that own facilities that participate to the scheme. Our empirical approach aims at creating a proper counterfactual for treated firms to obtain unbiased estimates of the treatment effect.

Treated firms seem to have gained from the EU ETS, contrarily to the predictions of the traditional approach. Our results suggest that the EU ETS has positively affected turnover, markup, investment intensity and labour productivity. Emission intensity of EU ETS firms is not related to their performance. Finally, firms that exit the ETS (but remain on the market) experience a substantial drop in size.

While our work provides some tentative explanation about the possible reasons that may explain our results, a comprehensive assessment of the mechanisms is beyond the scope of this paper. Further research is needed to identify these mechanisms and quantify their contribution to explaining the link (or absence thereof) between the EU

\footnotetext{
${ }^{\dagger \dagger \dagger}$ Differences in outcome for entrant firms during Phase I have no influence on the assessment of the impact of the ETS on performance as these firms were not assigned to treatment in 2005-2007.
} 
ETS and economic performance. In what follows, we suggest a series of possible mechanisms that may help interpreting.

The first mechanism derives directly from our results. Pass through of the additional costs induced by the EU ETS to their customers, evidenced by higher markup, has led to an increase turnover. In this framework, further research is needed to evaluate whether pass-through has had an influence on the international competitiveness of European firms. A second mechanism at work is the capital deepening effect that we infer from our results. Firms responded to the ETS by increasing their investment rate (even though results for investment are not robust throughout the specifications) and, consequently, labour productivity.

As suggested by recent contributions, environmental policy that stimulates innovation may lead to positive innovation-related outcomes, which could, in turn, more than offset the negative effect of compliance costs on competitiveness and economic performance (Porter and van der Linde, 1995). Calel and Dechezleprêtre (2016) find that the EU ETS increased by 10 percent the patenting activity in low carbon innovations. This link between environmental policy and induced innovation may be a possible explanation of a positive effect of the EU ETS on firm performance. It should be noted, however, that, on the one hand, the returns from innovation are likely to arise only in the medium-long run and, on the other hand, the innovation induced effect of the EU ETS estimated by Calel and Dechezleprêtre (2016) is quite small in magnitude.

Other mechanisms relate to the way the EU ETS has been implemented. The EU ETS was designed to limit its possible negative consequences on the economic performance of the EU industry. Thus, in the first two phases, the overall cap was quite high compared to historical emissions and, more importantly, the cap did not account for the collapse of industrial output in Europe during the Great Recession. Allocation to manufacturing sectors was particularly generous: according to our calculations, emission permits allocated for free to installations that operate in the manufacturing sector were about 24 percent larger than the corresponding verified emissions, on average, over the period 2005-2012, whereas for other sectors they were about 8 percent below verified emissions. The high cap resulted into very low prices on the market for permits, thus reducing the cost of complying with the EU ETS even for emission- 
intensive manufacturing sectors (Koch et al, 2014). These favourable conditions for EU ETS firms were, at least to some extent, the outcome of a successful lobbying activity exercised by EU ETS companies and sectors on European authorities, as suggested by recent literature (e.g. Markussen and Svendsen, 2005; Svendsen, 2005; Böhringer and Rosendahl, 2009).

As suggested by Hepburn et al. (2006), these favourable conditions could have even reduced compliance costs for EU ETS sectors compared with other non-ETS sectors. Consequently, economic performance of treated firms has not been harmed, but even enhanced in relative terms. 


\section{References}

[1] Abadie, A. (2005). Semiparametric Difference-in-Differences estimators. Review of Economic Studies, 72(1), 1-19.

[2] Abadie, A., and Imbens, G. W (2006). Large sample properties of matching estimators for average treatment effects. Econometrica, 74(1), 235-267.

[3] Abrell, J., Ndoye Faye, A., and Zachmann, G. Assessing the impact of the EU ETS using firm level data. Bruegel Working Paper, 2011.

[4] Ackerberg, D., Caves, K., and Frazer, G. (2006) Structural identification of production functions, MPRA Paper No. 38349.

[5] Anger, N., and Oberndorfer, U. (2008). Firm performance and employment in the EU emissions trading scheme: an empirical assessment for Germany. Energy Policy, 36(1), 12-22.

[6] Baumol, W. J., and Oates, W. E. (1988). The theory of environmental policy. Cambridge University Press.

[7] Böhringer, C., and Rosendahl, K. E. (2009). Strategic partitioning of emission allowances under the EU Emission Trading Scheme. Resource and Energy Economics, 31(3), 182-197.

[8] Calel, R. and Dechezleprêtre, A. (2016). Environmental policy and directed technological change: evidence from the European carbon market. Review of Economics and Statistics, 98(1), 173-191.

[9] Caliendo, M., and Kopeinig, S. (2008). Some practical guidance for the implementation of propensity score matching. Journal of Economic Surveys, 22(1), 31-72.

[10] Chan, H. S. R., Li, S., and Zhang, F. (2013). Firm competitiveness and the European Union emissions trading scheme. Energy Policy, 63, 1056-1064.

[11] Coase, Ronald H. The Coase theorem and the empty core: a comment. Journal of Law and Economics, 1981, 183-187.

[12] Commins, N., Lyons, S., Schiffbauer, M., and Tol, R. S. J. (2011). Climate policy and corporate behaviour. The Energy Journal, 32(4), 51-68.

[13] Convery, F. J. (2009). Reflections - the emerging literature on emissions trading in Europe. Review of Environmental Economics and Policy, 3(1): 121-137.

[14] De Loecker, J. (2011). Recovering markups from production data. International Journal of Industrial Organization, 29(3), 350-355. 
[15] De Loecker, J. and Warzynski, F. (2012). Markups and firm-level export status. American Economic Review, 102, 2437-2471.

[16] Demailly, D. and Quirion, P. (2008). European Emission Trading Scheme and competitiveness: a case study on the iron and steel industry. Energy Economics, 30(4), 2009-2027.

[17] Fabra, N. and Mar, R. (2014). Pass-through of emissions costs in electricity markets. American Economic Review, 104(9), 2872-99.

[18] Hepburn, C., Grubb, M., Neuhoff, K., Matthes, F., and Tse, M. (2006). Auctioning of EU ETS phase II allowances: how and why? Climate Policy, 6(1), 137-160.

[19] Jaraite, J.; and Di Maria, C. (2015). Did the EU ETS make a difference? An empirical assessment using Lithuanian firm-level data. The Energy Journal, 37(1), $1-23$.

[20] Koch, N., Fuss, S., Godefroy, G., and Edenhofer, O. (2014). Causes of the EU ETS price drop: recession, CDM, renewable policies or a bit of everything? New evidence. Energy Policy, 2014, 73, 676-685.

[21] Levinsohn, J., and Petrin, A. (2003). Estimating production functions using inputs to control for unobservables. Review of Economic Studies, 70, 317-341.

[22] Markussen, P., and Svendsen, G. T. (2005). Industry lobbying and the political economy of GHG trade in the European Union. Energy Policy, 33(2), 245-255.

[23] Martin, R., Muûls, M., and Wagner, U. J. (2016). The impact of the EU ETS on regulated firms: what is the evidence after ten years?. Review of Environmental Economics and Policy, 10(1), 129-148.

[24] Martin, R., Muûls, M., De Preux, L. B., and Wagner, U. J. (2014). Industry compensation under relocation risk: a firm-level analysis of the EU Emissions Trading Scheme. American Economic Review, 104(8), 2482-2508.

[25] Palmer, K., Oates, W. E., and Portney, P. R. (1995). Tightening environmental standards: the benefit-cost or the no-cost paradigm? Journal of Economic Perspectives, 9(4), 119-132.

[26] Petrick, S., and Wagner, U. J. (2014). The impact of carbon trading on industry: evidence from German manufacturing firms. Working paper.

[27] Partnership for Market Readiness, International Carbon Action Partnership. (2016). Emission Trading in Practice: A Handbook on Design and Implementation. World Bank.

[28] Rosenbaum, P. R., and Rubin, D. (1985). B. Constructing a control group using multivariate matched sampling methods that incorporate the propensity score. The American Statistician (39), 33-38. 
[29] Sijm, J., Neuhoff, K., and Chen, Y. (2006). $\mathrm{CO}_{2}$ cost pass-through and windfall profits in the power sector. Climate Policy, 6(1), 49-72.

[30] Svendsen, G. T. (2005). Lobbying and $\mathrm{CO}_{2}$ trade in the EU. In Emissions Trading for Climate Policy: US and European Perspectives. Cambridge University Press, $150-161$.

[31] Wagner, U., Muûls, M., Martin, R., and Colmer, J. (2014). The causal effects of the European Union Emissions Trading Scheme: evidence from French manufacturing plants. Working paper. 


\section{Tables and figures}

Table 1 - EU ETS installations linked to firms in Amadeus (by country)

\begin{tabular}{lcc}
\hline Country & $\begin{array}{c}\text { EU ETS } \\
\text { installations }\end{array}$ & EU ETS firms \\
\hline Austria & 144 & 83 \\
Belgium & 273 & 193 \\
Czech Republic & 377 & 239 \\
Denmark & 98 & 53 \\
Estonia & 15 & 13 \\
Finland & 184 & 61 \\
France & 219 & 119 \\
Germany & 444 & 429 \\
Hungary & 184 & 127 \\
Italy & 517 & 335 \\
Latvia & 21 & 21 \\
Netherlands & 143 & 105 \\
Poland & 521 & 285 \\
Portugal & 198 & 171 \\
Slovakia & 155 & 109 \\
Slovenia & 70 & 65 \\
Spain & 831 & 641 \\
Sweden & 163 & 118 \\
United Kingdom & 473 & 278 \\
\hline Total & 5030 & 3445 \\
\hline
\end{tabular}

Table 2 - Distribution of firms in the operative sample by country

\begin{tabular}{lccc}
\hline Country & $\begin{array}{c}\text { EU ETS } \\
\text { installations }\end{array}$ & EU ETS firms & Total firms \\
\hline Austria & 94 & 51 & 928 \\
Belgium & 150 & 114 & 1793 \\
Czech Republic & 137 & 98 & 2058 \\
Denmark & 83 & 42 & 504 \\
Estonia & 9 & 8 & 166 \\
Finland & 74 & 35 & 830 \\
France & 166 & 84 & 6533 \\
Germany & 158 & 145 & 5219 \\
Hungary & 77 & 43 & 973 \\
Ireland & 4 & 2 & 287 \\
Italy & 296 & 185 & 10366 \\
Latvia & 11 & 11 & 173 \\
Netherlands & 36 & 24 & 1106 \\
Poland & 350 & 155 & 2728 \\
Portugal & 68 & 52 & 976 \\
Slovakia & 46 & 39 & 481 \\
Slovenia & 52 & 47 & 417 \\
Spain & 422 & 264 & 4473 \\
Sweden & 122 & 83 & 1680 \\
United Kingdom & 312 & 154 & 6286 \\
\hline Total & 2667 & 1636 & 47977 \\
\hline
\end{tabular}


Table 3 - Distribution of firms in the operative sample by sector

\begin{tabular}{|c|c|c|c|c|}
\hline \multicolumn{2}{|c|}{ Sector } & \multirow{2}{*}{$\begin{array}{c}\begin{array}{c}\text { EU ETS } \\
\text { installations }\end{array} \\
437\end{array}$} & \multirow{2}{*}{$\begin{array}{c}\text { EU ETS firms } \\
235\end{array}$} & \multirow{2}{*}{$\begin{array}{c}\text { Total firms } \\
6477\end{array}$} \\
\hline 10 & Food products & & & \\
\hline 11 & Beverages & 97 & 67 & 1432 \\
\hline 12 & Tobacco products & 5 & 5 & 274 \\
\hline 13 & Textiles & 35 & 33 & 1242 \\
\hline 14 & Wearing apparel & 5 & 5 & 1442 \\
\hline 15 & Leather and related products & 2 & 2 & 854 \\
\hline 16 & Wood and of products of wood and cork & 88 & 55 & 1399 \\
\hline 17 & Paper and paper products & 403 & 278 & 1431 \\
\hline 18 & Printing and reproduction of recorded media & 4 & 4 & 1001 \\
\hline 19 & Coke and refined petroleum products & 79 & 50 & 239 \\
\hline 20 & Chemicals and chemical products & 271 & 194 & 3059 \\
\hline 21 & Pharmaceutical products & 56 & 40 & 1074 \\
\hline 22 & Rubber and plastic products & 48 & 38 & 3120 \\
\hline 23 & Other non-metallic mineral products & 720 & 357 & 2153 \\
\hline 24 & Basic metals & 186 & 117 & 1816 \\
\hline 25 & Fabricated metal products & 33 & 26 & 5414 \\
\hline 26 & Computer, electronic and optical products & 10 & 9 & 2105 \\
\hline 27 & Electrical equipment & 32 & 16 & 2236 \\
\hline 28 & Machinery and equipment n.e.c. & 35 & 24 & 5191 \\
\hline 29 & Motor vehicles, trailers and semi-trailers & 62 & 44 & 1762 \\
\hline 30 & Other transport equipment & 44 & 24 & 742 \\
\hline 31 & Furniture & 3 & 3 & 1119 \\
\hline 32 & Other manufacturing & 11 & 9 & 1434 \\
\hline \multirow[t]{2}{*}{33} & Repair and installation of machinery and equipment & 1 & 1 & 961 \\
\hline & Total & 2667 & 1636 & 47977 \\
\hline
\end{tabular}


Table 4 - Propensity score estimates

\begin{tabular}{|c|c|c|c|c|c|c|c|c|c|}
\hline & (1) & (2) & (3) & (4) & $(5)$ & (6) & (7) & (8) & (9) \\
\hline $\begin{array}{l}\text { Dependent var: } \\
\text { ETS=1 }\end{array}$ & $\begin{array}{l}\text { Outcome: } \\
\log (\mathrm{empl})\end{array}$ & $\begin{array}{c}\text { Outcome: } \\
\text { log(av_wage })\end{array}$ & $\begin{array}{l}\text { Outcome: } \\
\log (\text { turn })\end{array}$ & $\begin{array}{l}\text { Outcome: } \\
\log (\mathrm{VA})\end{array}$ & $\begin{array}{l}\text { Outcome: } \\
\text { Markup }\end{array}$ & $\begin{array}{c}\text { Outcome: } \\
\text { GFCF/assets }\end{array}$ & $\begin{array}{l}\text { Outcome: } \\
\log (\mathrm{VA} / \mathrm{L})\end{array}$ & $\begin{array}{l}\text { Outcome: } \\
\text { TFP }\end{array}$ & $\begin{array}{l}\text { Outcome } \\
\text { ROI }\end{array}$ \\
\hline $\log ($ empl $)$ & $\begin{array}{l}0.611 * * * \\
(0.0207)\end{array}$ & $\begin{array}{l}0.572 * * * \\
(0.0212)\end{array}$ & $\begin{array}{l}0.394 * * * \\
(0.0451)\end{array}$ & $\begin{array}{c}0.615 * * * \\
(0.173)\end{array}$ & $\begin{array}{c}0.536 * * * \\
(0.0333)\end{array}$ & $\begin{array}{l}0.563 * * * \\
(0.0190)\end{array}$ & $\begin{array}{l}0.599 * * * \\
(0.0217)\end{array}$ & $\begin{array}{c}0.603 * * * \\
(0.0237)\end{array}$ & $\begin{array}{l}0.568 * * * \\
(0.0194)\end{array}$ \\
\hline Growth empl & $\begin{array}{l}-0.0449 \\
(0.0581)\end{array}$ & $\begin{array}{c}0.0777 \\
(0.0813)\end{array}$ & $\begin{array}{l}-0.0332 \\
(0.0506)\end{array}$ & $\begin{array}{l}-0.0819 \\
(0.0586)\end{array}$ & $\begin{array}{l}-0.0646 \\
(0.0778)\end{array}$ & $\begin{array}{l}-0.0144 \\
(0.0446)\end{array}$ & $\begin{array}{c}0.0847 \\
(0.0843)\end{array}$ & $\begin{array}{l}-0.0480 \\
(0.0709)\end{array}$ & $\begin{array}{l}-0.0264 \\
(0.0439)\end{array}$ \\
\hline $\log (\mathrm{K} / \mathrm{L})$ & $\begin{array}{c}0.503 * * * \\
(0.0306)\end{array}$ & $\begin{array}{c}0.490 * * * \\
(0.0307)\end{array}$ & $\begin{array}{c}0.452 * * * \\
(0.0299)\end{array}$ & $\begin{array}{c}0.465 * * * \\
(0.0322)\end{array}$ & $\begin{array}{c}0.416 * * * \\
(0.0588)\end{array}$ & $\begin{array}{l}0.476 * * * \\
(0.0287)\end{array}$ & $\begin{array}{c}0.483 * * * \\
(0.0329)\end{array}$ & $\begin{array}{c}0.528 * * * \\
(0.0396)\end{array}$ & $\begin{array}{l}0.432 * * * \\
(0.0317)\end{array}$ \\
\hline $\log (\mathrm{VA} / \mathrm{L})$ & $\begin{array}{c}0.316^{* * *} \\
(0.0511)\end{array}$ & $\begin{array}{c}0.116^{*} \\
(0.0626)\end{array}$ & $\begin{array}{l}0.146 * * \\
(0.0584)\end{array}$ & $\begin{array}{c}0.380 * * \\
(0.174)\end{array}$ & $\begin{array}{c}0.283 * * * \\
(0.0710)\end{array}$ & $\begin{array}{l}0.273 * * * \\
(0.0464)\end{array}$ & $\begin{array}{c}0.872 * * \\
(0.362)\end{array}$ & $\begin{array}{c}0.325 * * * \\
(0.0679)\end{array}$ & $\begin{array}{c}0.448 * * * \\
(0.0592)\end{array}$ \\
\hline Age & $\begin{array}{c}0.000339 \\
(0.000810)\end{array}$ & $\begin{array}{l}-0.000134 \\
(0.000924)\end{array}$ & $\begin{array}{c}0.000412 \\
(0.000815)\end{array}$ & $\begin{array}{c}0.000254 \\
(0.000900)\end{array}$ & $\begin{array}{l}0.000758 \\
(0.00104)\end{array}$ & $\begin{array}{c}0.000325 \\
(0.000793)\end{array}$ & $\begin{array}{c}0.000288 \\
(0.000930)\end{array}$ & $\begin{array}{c}0.000720 \\
(0.000987)\end{array}$ & $\begin{array}{c}0.000241 \\
(0.000814)\end{array}$ \\
\hline $\log ($ av_wage $)$ & & $\begin{array}{c}0.594 * * * \\
(0.111)\end{array}$ & & & & & & & \\
\hline Growth av_wage & & $\begin{array}{l}0.0447 \\
(0.122)\end{array}$ & & & & & & & \\
\hline $\log ($ turn $)$ & & & $\begin{array}{c}0.229 * * * \\
(0.0450)\end{array}$ & & & & & & \\
\hline Growth turn & & & $\begin{array}{l}0.00486 \\
(0.0731)\end{array}$ & & & & & & \\
\hline $\log (\mathrm{VA})$ & & & & $\begin{array}{l}-0.0105 \\
(0.173)\end{array}$ & & & & & \\
\hline Growth VA & & & & $\begin{array}{c}0.0843 \\
(0.0555)\end{array}$ & & & & & \\
\hline Markup & & & & & $\begin{array}{c}0.618 * * * \\
(0.231)\end{array}$ & & & & \\
\hline Growth Markup & & & & & $\begin{array}{c}0.179 \\
(0.417)\end{array}$ & & & & \\
\hline GFCF/assets & & & & & & $\begin{array}{l}-0.182 \\
(0.189)\end{array}$ & & & \\
\hline Growth GFCF/assets & & & & & & $\begin{array}{l}0.0467 \\
(0.123)\end{array}$ & & & \\
\hline Growth VA/L & & & & & & & $\begin{array}{c}0.125^{*} \\
(0.0681)\end{array}$ & & \\
\hline TFP & & & & & & & & $\begin{array}{c}0.102 \\
(0.178)\end{array}$ & \\
\hline Growth TFP & & & & & & & & $\begin{array}{c}0.458 \\
(0.471)\end{array}$ & \\
\hline ROI & & & & & & & & & $\begin{array}{c}-1.409 * * * \\
(0.362)\end{array}$ \\
\hline Growth ROI & & & & & & & & & $\begin{array}{c}1.277 * * * \\
(0.367)\end{array}$ \\
\hline $\begin{array}{l}\text { Pseudo R sq } \\
\mathrm{N}\end{array}$ & $\begin{array}{l}0.425 \\
15042\end{array}$ & $\begin{array}{l}0.428 \\
14599\end{array}$ & $\begin{array}{l}0.423 \\
15504\end{array}$ & $\begin{array}{l}0.425 \\
14469\end{array}$ & $\begin{array}{l}0.381 \\
11028\end{array}$ & $\begin{array}{l}0.413 \\
16880\end{array}$ & $\begin{array}{l}0.426 \\
13594\end{array}$ & $\begin{array}{l}0.419 \\
11774\end{array}$ & $\begin{array}{l}0.417 \\
15726\end{array}$ \\
\hline
\end{tabular}

Probit estimator. Dependent variable: treatment. Explanatory variables are measured in 2003 (growth rates for year 2003-2004). Sector-year dummies included. Firms in country-sector cells with no treated firms are excluded from the estimation of the propensity score. Standard errors in parenthesis. ${ }^{*} \mathrm{p}<0.1,{ }^{* *} \mathrm{p}<0.05,{ }^{* * *} \mathrm{p}<0.01$. 
Table 5 - Composition of estimation samples

\begin{tabular}{lcccc}
\hline & $\begin{array}{c}\text { Treated firms with } \\
\text { common support }\end{array}$ & $\begin{array}{c}\text { Off support or } \\
\text { unmatched treated firms }\end{array}$ & $\begin{array}{c}\text { Matched control firms } \\
\text { (with 10 nearest } \\
\text { neighbour and } \\
\text { caliper=0.05) }\end{array}$ & $\begin{array}{c}\text { Average number of } \\
\text { matched controls per } \\
\text { treated }\end{array}$ \\
\hline $\log (\mathrm{empl})$ & 687 & 297 & 2567 & 3.7 \\
$\log (\mathrm{av}$ _wage) & 654 & 248 & 2414 & 3.7 \\
$\log ($ turn) & 728 & 284 & 2722 & 3.7 \\
$\log (\mathrm{VA})$ & 659 & 275 & 2489 & 3.8 \\
Markup & 481 & 167 & 1935 & 4.0 \\
GFCF/assets & 754 & 275 & 2919 & 3.9 \\
$\log (\mathrm{VA} / \mathrm{L})$ & 614 & 270 & 2352 & 3.8 \\
TFP & 557 & 221 & 2046 & 3.7 \\
ROI & 713 & 284 & 2740 & 3.8 \\
\hline
\end{tabular}

Table 6 - Balancing properties of the matching (pre-treatment level and growth of the outcome variables)

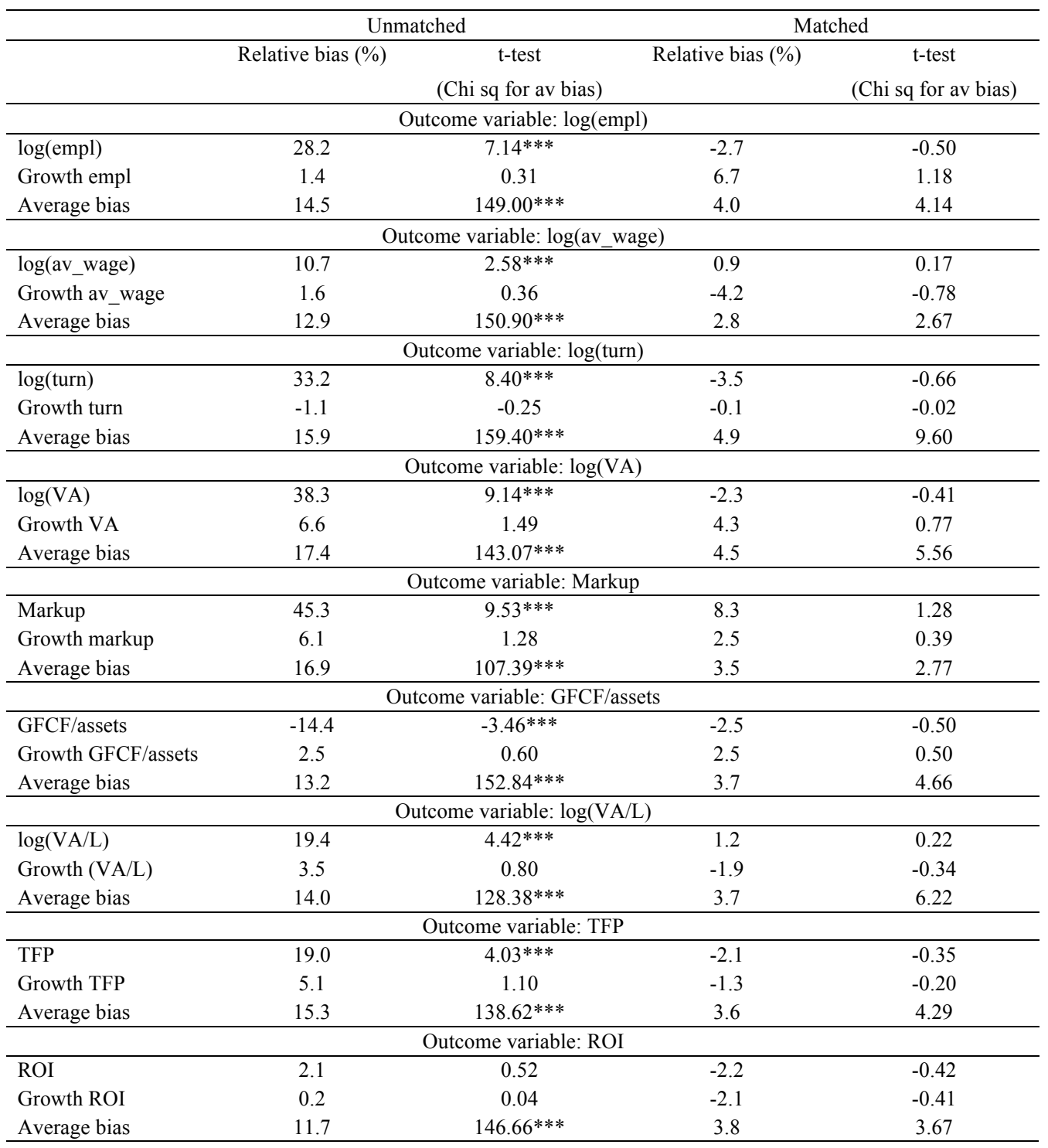


$* \mathrm{p}<0.1, * * \mathrm{p}<0.05, * * * \mathrm{p}<0.01$ 
Table 7 - Balancing properties of the matching (remaining covariates)

\begin{tabular}{|c|c|c|c|c|}
\hline & \multicolumn{2}{|c|}{ Unmatched } & \multicolumn{2}{|c|}{ Matched } \\
\hline & Relative bias (\%) & t-test & Relative bias & t-test \\
\hline \multicolumn{5}{|c|}{ Outcome variable: $\log (\mathrm{empl})$} \\
\hline $\log (\mathrm{empl})$ & 86.2 & $33.50 * * *$ & -6.1 & -1.36 \\
\hline Growth empl & -2.4 & -0.78 & -5.3 & -1.38 \\
\hline $\log (\mathrm{K} / \mathrm{L})$ & 92.5 & $31.69 * * *$ & 6.8 & $1.69 *$ \\
\hline $\log (\mathrm{VA} / \mathrm{L})$ & 35.5 & $12.93 * * *$ & 6.2 & 1.49 \\
\hline Age & 22.1 & $8.83 * * *$ & 0.7 & 0.16 \\
\hline \multicolumn{5}{|c|}{ Outcome variable: $\log ($ av wage $)$} \\
\hline $\log (\mathrm{empl})$ & 87.4 & $32.84 * * *$ & -4.1 & -0.86 \\
\hline Growth empl & 0.1 & 0.05 & -0.4 & -0.09 \\
\hline $\log (\mathrm{K} / \mathrm{L})$ & 94.9 & $31.14 * * *$ & 5.6 & 1.28 \\
\hline $\log (\mathrm{VA} / \mathrm{L})$ & 35.3 & $12.62 * * *$ & 7.6 & $1.71 *$ \\
\hline Age & 19.1 & $7.23 * * *$ & -2.9 & -0.60 \\
\hline \multicolumn{5}{|c|}{ Outcome variable: $\log$ (turn) } \\
\hline $\log (\mathrm{empl})$ & 88.6 & $34.39 * * *$ & -5.9 & -1.30 \\
\hline Growth empl & -1.8 & -0.59 & -3.6 & -0.81 \\
\hline $\log (\mathrm{K} / \mathrm{L})$ & 92.3 & $31.53 * * *$ & 7.0 & $1.74 *$ \\
\hline $\log (\mathrm{VA} / \mathrm{L})$ & 35.2 & $12.88 * * *$ & 5.6 & 1.36 \\
\hline Age & 25.3 & $9.01 * * *$ & -1.6 & -0.33 \\
\hline \multicolumn{5}{|c|}{ Outcome variable: $\log$ (VA) } \\
\hline $\log (\mathrm{empl})$ & 87.7 & $35.85 * * *$ & -7.2 & -1.54 \\
\hline Growth empl & -2.3 & -0.77 & -1.4 & -0.33 \\
\hline $\log (\mathrm{K} / \mathrm{L})$ & 94.6 & $31.02 * * *$ & 8.8 & $2.16 * *$ \\
\hline $\log (\mathrm{VA} / \mathrm{L})$ & 39.3 & $13.58 * * *$ & 4.3 & 1.00 \\
\hline Age & 20.5 & $7.76 * * *$ & -3.5 & -0.74 \\
\hline \multicolumn{5}{|c|}{ Outcome variable: Markup } \\
\hline $\log (\mathrm{empl})$ & 83.8 & $25.32 * * *$ & -8.6 & -1.49 \\
\hline Growth empl & 1.4 & 0.35 & 2.4 & 0.47 \\
\hline $\log (\mathrm{K} / \mathrm{L})$ & 92.8 & $24.30 * * *$ & 7.9 & $1.80 *$ \\
\hline $\log (\mathrm{VA} / \mathrm{L})$ & 39.7 & $11.08 * * *$ & 3.9 & 0.79 \\
\hline Age & 20.8 & $6.52 * * *$ & -0.1 & -0.02 \\
\hline \multicolumn{5}{|c|}{ Outcome variable: GFCF/assets } \\
\hline $\log (\mathrm{empl})$ & 90.2 & $34.51 * * *$ & -9.6 & $-2.11 * *$ \\
\hline Growth empl & -2.6 & -0.82 & -0.9 & -0.24 \\
\hline $\log (\mathrm{K} / \mathrm{L})$ & 91.4 & $31.19 * * *$ & 7.8 & $1.99 * *$ \\
\hline $\log (\mathrm{VA} / \mathrm{L})$ & 35.2 & $12.81 * * *$ & 3.7 & 0.89 \\
\hline Age & 22.2 & $8.87 * * *$ & -4.8 & -1.01 \\
\hline \multicolumn{5}{|c|}{ Outcome variable: $\log (\mathrm{VA} / \mathrm{L})$} \\
\hline $\log (\mathrm{empl})$ & 87.5 & $32.56^{* * *}$ & -7.2 & -1.50 \\
\hline Growth empl & -0.1 & -0.04 & 1.2 & 0.29 \\
\hline $\log (\mathrm{K} / \mathrm{L})$ & 97.3 & $31.60 * * *$ & 9.8 & $2.35 * *$ \\
\hline $\log (\mathrm{VA} / \mathrm{L})$ & 40.8 & $13.89 * * *$ & 5.9 & 1.33 \\
\hline Age & 20.5 & $7.70 * * *$ & -1.9 & -0.39 \\
\hline \multicolumn{5}{|c|}{ Outcome variable: TFP } \\
\hline $\log (\mathrm{empl})$ & 92.3 & $30.60 * * *$ & -8.1 & -1.52 \\
\hline Growth empl & -3.2 & -0.92 & 3.4 & 0.73 \\
\hline $\log (\mathrm{K} / \mathrm{L})$ & 100.7 & $28.75 * * *$ & 9.0 & $2.04 * *$ \\
\hline $\log (\mathrm{VA} / \mathrm{L})$ & 45.9 & $13.71 * * *$ & 4.2 & 0.86 \\
\hline Age & 21.6 & $7.30 * * *$ & 0.3 & 0.06 \\
\hline \multicolumn{5}{|c|}{ Outcome variable: ROI } \\
\hline $\log (\mathrm{empl})$ & 86.7 & $33.46^{* * *}$ & -7.0 & -1.55 \\
\hline Growth empl & -1.8 & -0.59 & -4.9 & -1.24 \\
\hline $\log (\mathrm{K} / \mathrm{L})$ & 92.9 & $31.45 * * *$ & 7.3 & $1.82 *$ \\
\hline $\log (\mathrm{VA} / \mathrm{L})$ & 36.0 & $13.08 * * *$ & 7.7 & $1.83 *$ \\
\hline Age & 21.9 & $8.67 * * *$ & -0.4 & -0.08 \\
\hline
\end{tabular}

